\section{British Dental Receptionists' Association closes}

The British Dental Receptionists' Association (BDRA) will be discontinued from the end of the year due to an inability to attract members, according to its Development Advisor Glenys Bridges. The BDRA had to cancel its Annual Conference in March 2006 due to a lack of bookings, which had a serious effect upon the morale of the Executive, many of whom resigned and were consequently not replaced.

Glenys explained, 'Since our formation during 2002, a number of receptionists have freely given generously of their time and skills. Unfortunately we have not been able to attract enough active members to sustain the Association's growth.'

The BDRA has ceased to accept applications for membership renewals and new membership applications although full membership services will be provided to existing members until 31 December 2006.

From 1 January 2007, The Dental Resource Company will offer BDRA members free membership to the DRC Receptionists Group. They will receive a quarterly electronic newsletter, a telephone support line and discounted training opportunities. BDRA members wishing to subscribe should forward their email details to admin@dentalresource.com. Alternatively, BDRA members can become Associate Members of BADN for the duration of their remaining BDRA membership, and after it has expired can rejoin the BADN either as Full Members (dental nurse/receptionists) or as Honorary Associate Members (receptionists).

BDRA members will also be able to become Associate Members of BADN's Practice Managers' \& Receptionists' National Group, which is participating in BADN's Joint National Group Study Day at the Menzies Hotel in Glasgow on 1 December 2006.

For more information visit www. badn.org.uk. For membership enquiries regarding your BDRA membership visit www.bdra.co.uk.

\title{
A mouth's eye view
}

A photographer who takes pictures with a camera in his mouth has just released a book of the images he has produced. Using a pinhole camera, the miniature hardback Mouthpiece by Justin Quinnell features his visit to the dentist, portraits of friends and family, snakes, tortoises, alligators and angry cats, the everyday acts of having a bath, cleaning his teeth and eating his dinner.

All the pictures are taken with a pinhole camera and include a collection of landscape photographs with a through-the-mouth view of icons of world travel, such as Sydney Opera House, Hong Kong, St Mark's Square in Venice, the Sagrada Familia in Barcelona and the Lincoln Memorial in Washington.

A one-time Parliamentary and European Election Candidate, Justin has tirelessly

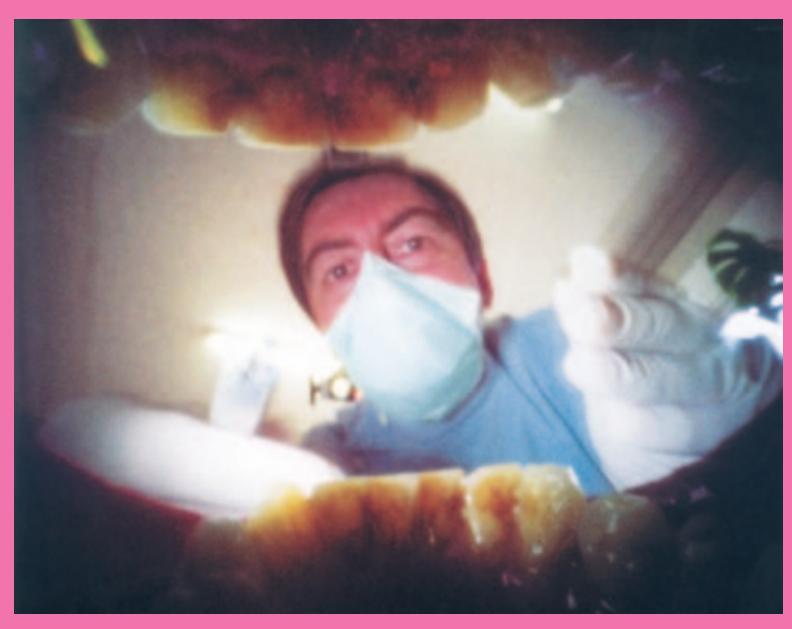
promoted pinhole photography for over 20 years. A recognised expert in the subject, he regularly lectures in the UK and abroad. A committed Green Party member he has also acted as publicist for a number of organisations including the National Cycle Network and World Pinhole Day. For more information visit www.pinholephotography.org.
Hygiene

and therapy

\section{aroural}

\section{launched}

Pfizer Consumer Healthcare has announced the launch of its first sponsorship award scheme to support training and development in major dental schools across the UK.

The Listerine Hygiene and Therapy Award will centre on a plaque viability experiment, demonstrating the importance of plaque management in the prevention of oral disease. The practical outputs from the experiment will form the basis of award entries.

The experiment, aimed at pre-clinical dental and hygiene and therapy students, demonstrates the influence a commercially available mouthwash might have on plaque viability. This experiment, devised by Glasgow University's Clinical Senior Lecturer in Oral Sciences, Steve Creanor, shows how bacteria production can be slowed down and over time reduced with the addition of an essential oils mouthwash to an oral health regime.

To enter the award, each school will be required to register a note of intent and in return Pfizer Consumer Healthcare will provide the necessary equipment and supporting materials.

A team of Pfizer oral healthcare consultants will visit each participating school, deliver a tutorial introducing the scheme and provide tutorial packs developed for tutors and students together with a DVD demonstrating the experiment.

The scheme will commence on Monday 4 September 2006 and students will be required to submit their findings from the practical experiment no later than Friday 27 April 2007. The winning student, announced at the end of the academic year, will receive $£ 1,000$ for their dental school and an all expenses paid trip to an international conference during their second year. A separate award of $\mathfrak{1} 1,000$ is available for the tutor delivering the most innovative demonstration to their students.

To find out more information and to register your interest to take part in the scheme please call 01304616161. 